\title{
Maciej Łochowski
}

https://orcid.org/0000-0002-7285-713X

Katolicki Uniwersytet Lubelski Jana Pawła II

Instytut Pamięci Narodowej

\section{Co wydarzyło się w Lublinie na przełomie lipca i sierpnia 1944 roku? Przyczynek do dziejów politycznych Polski}

\begin{abstract}
Abstrakt: Artykuł porusza problem rywalizacji o władzę w Lublinie na przełomie lipca i sierpnia 1944 r. pomiędzy przedstawicielami Armii Krajowej i Delegatury Rządu na Kraj a polskimi komunistami wspieranymi przez Kreml. Akcja odzyskania władzy przez lokalnych przedstawicieli władz polskich w Londynie miała być realizowana jednocześnie z wystąpieniem zbrojnym w ramach operacji „Burza”. W krótkim okresie po dekonspiracji i rozpoczęciu jawnej działalności terenowi przedstawiciele Polskiego Państwa Podziemnego zostali aresztowani przez Sowietów i przetransportowani do ZSRS, gdzie trafili do obozów pod zarządem NKWD.
\end{abstract}

Słowa kluczowe: 1944, Polski Komitet Wyzwolenia Narodowego, Lublin, Delegatura Rządu, Armia Krajowa, Ludowe Wojsko Polskie, NKWD, ZSRS, Armia Czerwona.

Abstract: The article discusses the problem of competition for power between representatives of the Home Army and the Government Delegation for Poland on the one side and Polish communists supported by the Kremlin which took place in Lublin at the end of July and early August 1944. The regaining of power by the local representatives of the Polish government in exile in London was to take place simultaneously with the Operation "Tempest". Shortly after the disclosure, members of the Polish Underground State in Poland were arrested by the Soviets and transported to the USSR, where they were taken to NKVD special camps.

Keyw or ds: 1944, Polish Committee of National Liberation, Lublin, Government Delegation for Poland, Polish Home Army, Polish People's Army, NKVD, USRR, Red Army. 
Pod koniec lipca i na początku sierpnia 1944 r. władzę w województwie lubelskim, po opuszczeniu tych terenów przez niemiecką administrację, przejęły organy Polskiego Państwa Podziemnego (PPP). W sferze administracyjnej był to Okręgowy Delegat Rządu RP na Kraj, a wojskowej - Komendant Okręgu Armii Krajowej Lublin. Po zaledwie kilku dniach od momentu dekonspiracji, na skutek działania Polskiego Komitetu Wyzwolenia Narodowego (PKWN) oraz wspierających ich Sowietów, najwyżsi przedstawiciele lokalnych polskich władz zostali aresztowani. Tym samym komuniści rozpoczęli tworzenie zrębów „władzy ludowej”.

Prezentowany artykuł stanowi próbę zrekonstruowania wydarzeń, jakie miały miejsce w Lublinie na przełomie lipca i sierpnia 1944 r., ze szczególnym uwzględnieniem aktywności ujawnionych lokalnych organów PPP, relacji panujących między nimi a polskimi komunistami oraz przedstawicielami Armii Czerwonej i NKWD.

Głównym celem polskich władz było uświadomienie zbliżajacym się do granic Polski Sowietom oraz opinii międzynarodowej, że na wyzwolonym spod okupacji niemieckiej terytorium Rzeczypospolitej jedyny prawowity gospodarz to aparat urzędniczy, który podlega rządowi w Londynie ${ }^{1}$. Żywiono nadzieję na to, że uda się przejąć władzę, wykorzystując krótką czasową lukę pomiędzy ewakuacją Niemców a wkroczeniem Armii Czerwonej i instalacja komunistycznej administracji ${ }^{2}$. Jednocześnie przewidywano rozpoczęcie przez

1 „Myślą przewodnią naszej ostatecznej walki - napisał w meldunku z 14 VII 1944 r. gen. Tadeusz Komorowski - jest: a) zadokumentowanie przed światem naszego nieugiętego stanowiska wobec Niemców i niezłomnej woli walki z nimi, b) wyrwanie Sowietom złośliwego atutu do zaliczania nas w poczet cichych sprzymierzeńców Niemiec, lub nawet tylko neutralnych w stosunku do Niemców, c) wzięcie pod swe d[owódz]two tej części społeczeństwa, która jest żądna odwetu na Niemcach [...] celem skierowania impulsu walki na drogę dążeń niepodległościowych i oderwania od czynników prosowieckich”. Armia Krajowa $w$ dokumentach 1939-1945, red. T. Pełczyński i in., t. III, Wrocław-Warszawa-Kraków 1990, s. 548 (dok. nr 664).

${ }^{2}$ Polskie podziemie rządowe doskonale zdawało sobie sprawę z tego, że komuniści przygotowuja się do utworzenia swego rządu w Polsce. W instrukcji dowódcy AK z 4 V 1944 r. czytamy: „Dywersja sowiecka wystapi niewątpliwie pod wieloraka postacia. Przede wszystkim pod pokrywą uzasadnionych działań operacyjnych nastapi zapewne próba wojskowego opanowania terenu przez oddziały dywersyjne, wzmocnione ost-legionami oraz AL. Równocześnie może być podjęta próba politycznego opanowania Kraju przez utworzenie «rządu ludowego» pod hasłami ogólno-demokratycznymi”. T. Żenczykowski, Polska lubelska 1944, Warszawa 1990, s. 246 (dok. nr 3). 17 VI 1944 r. gen. Komorowski depeszował do Londynu: „Komuna planuje ogłoszenie rządu w Kraju natychmiast po wkroczeniu wojsk sowieckich do Polski centralnej. Lublin i Białystok wymieniane jako miejsce utworzenia tego rządu". Armia Krajowa $w$ dokumentach..., s. 483 (dok. nr 639). W ZSRS jednym z najzagorzalszych zwolenników utworzenia rządu komunistycznego, mającego zastapić władze emigracyjne, był gen. Zygmunt Berling. Pomysł narodził się w połowie $1943 \mathrm{r}$. Naciskał on w tej kwestii na Wandę Wasilewską mającą dostęp do najwyższych sowieckich decydentów. We wrześniu 1943 r. Wasilewska przedstawiła mu negatywna odpowiedź Wiaczesława Mołotowa w sprawie utworzenia Polskiego Komitetu Narodowego. Pod koniec 1944 r. powrócono do rozmów 
oddziały Armii Krajowej (AK) operacji wojskowej o kryptonimie „Burza”, której celem były militarna osłona działań polskiej administracji oraz podjęcie wzmożonej aktywności bojowej przeciwko Niemcom.

Sowieci dobrze znali plany polskiego podziemia rządowego ${ }^{3}$. Józef Stalin wychodził z założenia, że na froncie wschodnim nie może istnieć, oprócz podporządkowanych mu wojsk oraz sił zbrojnych III Rzeszy, trzeci, niezależny czynnik, którego wystapienie w sferze militarnej skierowane byłoby przeciwko Niemcom, a politycznie przeciw ZSRS. Posiłkując się doniesieniami szpiegów (obecnych m.in. w administracji brytyjskiej i polskiej), władze sowieckie starały się wypracować plan działania względem AK i Delegatury Rządu RP na Kraj. Stawiali sobie za cel rozbrojenie i aresztowanie ujawniającej się polskiej konspiracji zbrojnej oraz likwidację administracji cywilnej. Ujawnionych oficerów AK planowano poddać represjom, a pozostałych żołnierzy wcielić do Ludowego Wojska Polskiego (LWP) ${ }^{5}$. Warto dodać, że tuż przed wkroczeniem

o utworzeniu władzy wykonawczej lub przedstawicielskiej. Na posiedzeniach komisji ds. utworzenia władz, mających miejsce na przełomie 1943 i 1944 r., rozpatrywano projekt deklaracji, strukturę organizacyjną oraz skład komitetu. W styczniu i lutym 1944 r. sprawę powołania rządu komunistycznego konsultowano z działaczami Polskiej Partii Robotniczej przebywającymi w okupowanym kraju. W miejscu tym należy zauważyć, że nowo wybrany na szefa partii Władysław Gomułka noca z 31 XII 1943 r. na 1 I 1944 r. utworzył, bez wiedzy moskiewskiej centrali, Krajową Radę Narodowa - rodzaj samozwańczego podziemnego parlamentu. Mieli w nim zasiadać komuniści oraz działacze innych ugrupowań politycznych popierajacych podstawowe cele PPR. Gomułka nie chciał dopuścić do tego, aby rząd komunistyczny był utworzony w ZSRS bez udziału KRN. Ważne - jak twierdził - było stwarzanie pozorów, iż władze komunistyczne powołane po wkroczeniu wojsk sowieckich mają krajową genezę i nie zostały przysłane z zewnątrz. W trakcie wizyt delegacji PPR w Moskwie w maju i czerwcu 1944 r. ustalono, iż w ZSRS zostanie utworzony organ wykonawczy KRN na ziemie wyzwolone spod okupacji niemieckiej. Ostatecznie jednak Polski Komitet Wyzwolenia Narodowego został powołany przez KRN jako oddzielne ciało polityczno-administracyjne, w którym poszczególni kierownicy resortów byli tymczasowymi naczelnymi organami władzy wykonawczej. Zob. A. Noskowa, Na drodze do stworzenia PKWN - rola Moskwy, „Pamięć i Sprawiedliwość” 2005, nr 2 (4), s. 35-48; P. Gontarczyk, Polska Partia Robotnicza. Droga do władzy 1941-1944, Warszawa 2006, s. 306-318; idem, Jak krawiec rozwiazat generalski problem, czyli prawda o PKWN, „Gazeta Polska”, 21 VII 2004, nr 29, s. 19; M. Wierzbicki, Polska lubelska (1944 r.), w: Dzieje Lubelszczyzny 1944-1956. Aspekty polityczne, red. T. Osiński, M. Mazur, Lublin 2016, s. 74-76; J. Eisler, Siedmiu wspaniałych. Poczet pierwszych sekretarzy KC PZPR, Warszawa 2014, s. 182-184; M. Kallas, Historia ustroju Polski, Warszawa 2007, s. 339.

${ }^{3}$ Należy mieć na uwadze, że czynionych przygotowań do powstania lub też innej dużej operacji militarnej strona polska nawet nie próbowała ukrywać. Przykładowo w jednym z czasopism konspiracyjnych AK napisano wprost: „Powstanie można wywołać tylko jeden - jedyny raz. I musi to być bezwarunkowo powstanie udane”. Akcja zbrojna? Tak - lecz ograniczona!, „Biuletyn Informacyjny”, 1 IV 1943, nr 13, s. 1-2.

${ }^{4}$ N. Iwanow, Powstanie Warszawskie widziane z Moskwy, Kraków 2010, s. 72-73.

${ }^{5} \mathrm{Na}$ temat służby akowców w Ludowym Wojsku Polskim zob. J. Poksiński, Żotnierze Armii Krajowej w ludowym Wojsku Polskim, w: Armia Krajowa. Dramatyczny epilog, red. K. Komorowski, Warszawa 1994, s. 131-151. 
Armii Czerwonej na obszar dzisiejszej Polski Stalin wydał dyrektywę, w której zabraniał zawierania jakichkolwiek porozumień z oddziałami polskiego podziemia niepodległościowego ${ }^{6}$.

Istotna rolę odgrywali również najpotężniejsi koalicjanci porozumienia antyhitlerowskiego - Stany Zjednoczone i Wielka Brytania. Państwa te były traktowane zarówno przez władze polskie, jak i polityków ZSRS jako najważniejsi sojusznicy w walce $\mathrm{z}$ Niemcami i mediatorzy $\mathrm{w}$ relacjach polsko-sowieckich. Rząd polski zdawał sobie sprawę z tego, że bez ich poparcia Polska bezpowrotnie utraci ziemie wschodnie na rzecz ZSRS, a być może również suwerenność i niepodległość. Władze Związku Sowieckiego natomiast zabiegały u zachodnich aliantów o bieżąca pomoc wojskowa, zwiększenie zaangażowania na froncie zachodnim (celem odciążenia Armii Czerwonej na wschodzie) oraz akceptację dla planów podporządkowania Europy Środkowo-Wschodniej po zakończeniu działań wojennych?

Przynależność państwowa terenów położonych na zachód od Bugu nie była kwestionowana przez Stalina ${ }^{8}$. Z tego względu władze polskie zdecydowały się na kontynuowanie akcji ujawnienia podległych struktur administracyjnych i wojskowych pomimo represji, jakie spotkały podziemie na wschodzie ${ }^{9}$.

${ }^{6}$ G. Motyka, Na białych Polaków obława. Wojska NKWD w walce $z$ polskim podziemiem 1944-1953, Kraków 2014, s. 107.

7 Politycy na Kremlu uważali, że najlepszą drogą do zabezpieczenia panowania sowieckiego w tej części świata będzie udział lokalnych komunistów w powojennych władzach. Zob. A. Noskowa, op. cit., s. 32.

${ }^{8}$ W styczniu 1944 r. Michał Hreczucha, przewodniczący Rady Najwyższej Ukraińskiej Socjalistycznej Republiki Sowieckiej, na posiedzeniu X sesji Rady Najwyższej ZSRS stwierdził, że poza granicami sowieckiej Ukrainy wyznaczonymi w 1939 r. pozostaja jeszcze niektóre rejony, które zamieszkują Ukraińcy „pragnący połączyć się z narodem tej samej krwi”. W swojej wypowiedzi Hreczucha zwrócił się do rządu Kraju Rad i Stalina o przyłączenie do USRS Chełmszczyzny, Hrubieszowa, Zamościa, Jarosławia i „innych zachodnich rejonów”. W marcu podobny referat wygłosił Nikita Chruszczow, przewodniczący Rady Narodowych Komisarzy USRS. „Naród ukraiński - stwierdził w trakcie VI sesji Rady Najwyższej USRS - będzie ubiegać się o przyłączenie do ukraińskiego radzieckiego państwa rdzennych ukraińskich ziem, jakimi są Chełmszczyzna, Hrubieszów, Zamość, Tomaszów, Jarosław”. W maju 1944 r. na Kremlu miało miejsce spotkanie przedstawicieli KRN ze Stalinem. Ustalono, iż wspomniane postulaty ukraińskich komunistów nie będą brane pod uwagę podczas wytyczania wschodniej granicy Polski. Z dużą dozą prawdopodobieństwa można przypuszczać, iż Chruszczow wiedział o powyższych rozmowach. Mimo to 20 VII 1944 r., kiedy Armia Czerwona rozpoczęła swój pochód przez tereny województwa lubelskiego, wystapił on do Stalina z prośbą o zgodę na utworzenie obwodu chełmskiego w ramach USRS ze stolica w Chełmie. Pismo Chruszczowa pozostało jednak bez odpowiedzi. Zob. A. Wawryniuk, Plany polityczne Chruszczowa w sprawie wtaczenia czesści powiatu radzyńskiego do Ukraińskiej Socjalistycznej Republiki Sowieckiej, „Radzyński Rocznik Humanistyczny” 2012, t. X, s. 53-65; idem, Wschodnia granica Polski w latach 1944-1948 na przyktadzie południowo-wschodniej Lubelszczyzny, „Archiwariusz Zamojski” 2012, s. 8-20.

9 Po realizacji operacji „Burza” we wschodniej Polsce przedstawicieli polskiego podziemia niepodległościowego aresztowano, a następnie poddano represjom. Dowództwo AK liczyło na to, że inny będzie stosunek Sowietów do PPP na Kresach Wschodnich (tereny te traktowane 
Lublin był pierwszym dużym polskim miastem położonym po zachodniej stronie Bugu i stanowił centrum polityczne, gospodarcze i administracyjne regionu. Z tych względów w trakcie spotkania w Moskwie 8 VII 1944 r., w którym uczestniczyli: Józef Stalin, marsz. Gieorgij Żukow, Bolesław Bierut, Edward Osóbka-Morawski oraz Michał Rola-Żymierski, uzgodniono, że to właśnie tam jawną działalność rozpocznie KRN, mająca charakter samozwańczego parlamentu ${ }^{10}$. Od tej chwili szybkie zajęcie miasta było dla wojsk sowieckich jednym $\mathrm{z}$ priorytetowych zadań ${ }^{11}$.

Podobne plany miała AK. W rozkazie z 1 VII 1944 r. dowódca Inspektoratu Rejonowego Lublin ppłk Edward Jasiński „Nurt” wezwał podległe mu oddziały „do najbardziej intensywnej pracy nad planem «A» [planem powstania powszechnego - M.Ł.] i «B» [planem wzmożonej operacji sabotażowo-dywersyjnej «Burza” - M.Ł.]”12. Najważniejszymi zadaniami AK stacjonującej w centralnej części okręgu było opanowanie Lublina, Lubartowa, Łęcznej oraz lotniska w Świdniku. Do walki o Lublin został wyznaczony garnizon AK oraz wydzielone plutony z Obwodu Lublin-powiat. Pozostałe oddziały stacjonujące na terenach podmiejskich miały zabezpieczać działania polskich żołnierzy w mieście poprzez odcięcie niemieckiego garnizonu od wsparcia z zewnątrz oraz sparaliżowanie działań ewakuacyjnych. Część sił Obwodu Lublin-powiat otrzymała polecenie koncentracji na południe od Lublina w rejonie Bychawy i Krzczonowa celem zabezpieczenia mającej tam stacjonować ekipy zastępczej komendy okręgu ${ }^{13}$.

były przez Stalina jako integralna część ZSRS), a inny na zachód od linii Curzona. Zob. Armia Krajowa $w$ dokumentach..., s. 550 (dok. nr 664); A. Chmielarz, Wtadze sowieckie i PKWN wobec AK w 1944 r., „Wojskowy Przegląd Historyczny” R. 37, 1992, nr 2, s. 29.

10 G. Żukow, Wspomnienia i refleksje, Warszawa 1970, s. 549.

1121 lipca miała miejsce konferencja na Kremlu, w której brali udział Stalin oraz przedstawiciele KRN i Związku Patriotów Polskich. Uzgodniono, iż siedzibą PKWN będzie Lublin. Tego dnia sowiecki dyktator wysłał do dowódcy 1 Frontu Białoruskiego dyrektywę nr 220149, w której oczekiwał, iż Armia Czerwona zajmie Lublin nie później niż 26-27 lipca. Sztab frontu podjał decyzję o natychmiastowym wysłaniu sił pancernych dowodzonych przez gen. Siemiona Bogdanowa do Lublina, bez odpowiedniego wsparcia piechoty. W miejscu tym warto dodać, iż 20 lipca Stalin otrzymał od Winstona Churchilla depeszę, w której był nakłaniany do podjęcia Stanisława Mikołajczyka w Moskwie, gdyż polski premier wyraził chęć rozpoczęcia negocjacji. Sowiecki dyktator chciał, aby rząd komunistyczny zaczął swoją działalność w dużym polskim mieście, jeszcze przed wylotem Mikołajczyka do Moskwy. Miało to stanowić ważną kartę przetargową w negocjacjach. Zob. T. Żenczykowski, op. cit., s. 22; I. Caban, Co się działo 22 lipca?, „Kamena”, 15 IV 1979, nr 8, s. 7; N. Bączyk, Czotgi idq na Lublin. Radzieckie wojska pancerne w szturmie Lublina w lipcu 1944 r., „Militaria XX Wieku” 2006, nr 1 (10), s. 68; B. Drobner, Bezustanna walka, t. III: Wspomnienia 1936-1944, Warszawa 1967, s. 204; Dokumenty i materiaty do historii stosunków polsko-radzieckich, t. VIII: Styczeń 1944 - grudzień 1945, oprac. E. Basiński i in., red. N. Gąsiorowska-Grabowska, I. Chrienow, Warszawa 1974, s. 142 (dok. nr 67).

${ }_{12}$ Zwiazek Walki Zbrojnej i Armia Krajowa w Okregu Lubelskim 1939-1944, cz. 2: Dokumenty, oprac. I. Caban, Z. Mańkowski, Lublin 1971, s. 402 (dok. nr 204).

${ }^{13}$ P. Gawryszczak, Podziemie polityczno-wojskowe $w$ Inspektoracie Lublin w latach 1944-1956, Lublin 1998, s. 31-32. 
Władze niemieckie wiedziały, że polskie podziemie może przystąpić do zbrojnego wystapienia na dużą skalę w decydujacym momencie wojny. „W związku z wydarzeniami na froncie - pisano w jednym z raportów - należy spodziewać się zaostrzenia sytuacji. Nie można jeszcze zorientować się, czy polski ruch oporu już teraz wywoła powszechne powstanie. Sztab wojskowy i policja zastosowały środki prewencyjne w miarę swych sił" ${ }^{14}$.

Wiadomo, że Niemcy nie zamierzali stawiać większego oporu na Lubelszczyźnie, gdyż główna linia obrony została wyznaczona na linii Wisły ${ }^{15}$. W Lublinie zdecydowano się na rozbudowę fortyfikacji wokół miasta oraz umocnienie niektórych budynków. Chodziło jedynie o opóźnienie marszu Sowietów, co miało umożliwić sprawną ewakuację aparatu okupacyjnego ${ }^{16}$. Do budowy obwarowań została skierowana ludność cywilna. Oprócz tego rozpoczęto masowe aresztowania pod fałszywym zarzutem przynależności do ruchu komunistycznego lub współpracy z nim ${ }^{17}$. Niemcy przystapili także do ewakuacji więzienia zorganizowanego na Zamku Lubelskim. Znaczna część aresztowanych została wówczas wysłana na stracenie do obozu koncentracyjnego na Majdanku. Ostatni etap likwidacji więzienia miał miejsce 22 VII 1944 r., tuż przed rozpoczęciem walki o miasto. Straż więzienna oraz komando egzekucyjne SS rozstrzelało blisko 200 polskich obywateli. Ponadto tego dnia wyprowadzono większość (ok. 800) więźniów obozu koncentracyjnego na Majdanku ${ }^{18}$.

18 lipca z rejonu Kowla wojska 1 Frontu Białoruskiego rozpoczęły natarcie w kierunku lubelskim. W ramach tego zwiazku operacyjnego działała także, dowodzona przez gen. Zygmunta Berlinga, 1 Armia Polska. 22 lipca wojska Stalina zajęły Chełm i Włodawę, a następnie wyszły na przedmieścia Lublina. Jednocześnie do wykonania operacji zbrojnej przystapiła AK. Pierwsi do walki włączyli się żołnierze Inspektoratu Chełm oraz Zamość, następnie oddziały stacjonujace $\mathrm{w}$ inspektoratach lubelskim, puławskim i radzyńskim. Garnizon AK rozpoczął walkę o Lublin 22 lipca. Przygotowane w sierpniu 1944 r. sprawozdanie z przebiegu operacji „Burza” w Inspektoracie Lublin

${ }^{14}$ Walka zbrojna $i$ działalność polskiego ruchu oporu $w$ świetle dokumentów niemieckich 1939-1945, oprac. i red. nauk. J. Gmitruk, P. Matusak, Warszawa 2018, s. 933-934 (dok. nr 573). O przygotowaniach Niemców do zdławienia powstania zob. np.: P. Lisiewicz, Plan „Burza”. Wysitek zbrojny Armii Krajowej 1944-1945, Warszawa 1990, s. 114-123.

${ }^{15}$ W. Churchill, Druga wojna światowa, tłum. K. Mosiewicz, t. VI, ks. 1, Gdańsk 1996, s. 135; J. Kasperek, Kronika wydarzeń w Lublinie w okresie okupacji hitlerowskiej, Lublin 1989, s. $254-255$.

${ }^{16}$ Z. Mańkowski, Okręg Lublin, w: Operacja „Burza” i Powstanie Warszawskie 1944, red. K. Komorowski, Warszawa 2008, s. 267.

${ }_{17}$ Zwiazek Walki Zbrojnej..., s. 465 (dok. nr 228); Meldunki sytuacyjne Komendy Okregu Lublin AK: maj-lipiec 1944, oprac. A.G. Kister, Lublin 1998, s. 87 (dok. nr 12).

${ }^{18}$ R. Szewczyk, Mord na Zamku Lubelskim $w$ dniu 22 lipca 1944, Warszawa 1946, s. 40; J. Kasperek, op. cit., s. 257. 
zawiera następującą informację: „Wśród Niemców, w samym m[ieście] Lublin - popłoch. Załoga m[iasta] Lublin mieszana, liczy około 2 b[atali]onów piechoty z 1 bateria artylerii lekkiej i 1 kompanii czołgów. Tymi siłami Niemcy nie sa zdolni [...] do obrony na przygotowanych pozycjach obronnych na zewnatrz m[iasta] Lublin, a tylko do obsadzenia i obrony poszczególnych ulic, względnie budynków w mieście"19.

W trakcie walk udało się polskim oddziałom zająć oraz zabezpieczyć szereg istotnych obiektów gospodarczych i przemysłowych, a także niektóre gmachy publiczne. Prowadzone były również akcje bojowe na przedmieściach Lublina, podczas których paraliżowano ewakuacje niemieckich kolumn. Czerwonoarmiści po wkroczeniu do miasta szybko nawiązali współpracę z AK. Polacy wspierali walczące w mieście sowieckie wojska pancerne oraz ze względu na dobra znajomość topografii Lublina wskazywali kierunki natarcia. Ostatnie odosobnione niemieckie punkty oporu upadły noca z 24 na 25 lipca $^{20}$.

23 lipca, gdy wynik walki o Lublin nie był jeszcze znany, Stalin przekazał Winstonowi Churchillowi i Franklinowi Delano Rooseveltowi następujaca informację:

Wydarzenia na naszym froncie rozgrywają się z błyskawiczną szybkością. Lublin, jedno z większych polskich miast, został wczoraj zajęty przez nasze wojska, które kontynuuja natarcie. W tych okolicznościach stajemy przed praktyczną kwestia administracji na terytorium polskim. Nie chcemy i nie będziemy wprowadzać swojej administracji na terytorium Polski, tak jak nie chcemy ingerować w wewnętrzne sprawy Polski. Powinni się tym zająć sami Polacy. Dlatego uznaliśmy za konieczne nawiązanie kontaktów z Polskim Komitetem Wyzwolenia Narodowego, utworzonym niedawno przez Krajową Rade Narodowa [...]. Polski Komitet Wyzwolenia Narodowego zamierza się zając tworzeniem administracji na terytorium polskim i mam nadzieję, że zostanie to zrealizowane. Nie znaleźliśmy w Polsce żadnych innych sił, które mogłyby stworzyć polską administrację. Tak zwane organizacje podziemne kierowane przez polski rząd w Londynie okazały się efemeryczne, pozbawione jakichkolwiek wpływów ${ }^{21}$.

${ }_{19}$ Archiwum Państwowe w Lublinie (dalej: APL), Związek Walki Zbrojnej-Armia Krajowa Okręg Lublin (dalej: ZWZ-AK Okręg Lublin), 516, Przebieg walk z Niemcami w okresie od 20 VII do 29 VII 1944 na terenie Inspektoratu Środkowego, sierpień 1944, k. 4. Zdaniem Ireneusza Cabana niemiecki garnizon Lublina liczył ok. 4300 ludzi. Dowodził nim gen. Hjalmar Moser. Zob. I. Caban, Co sie działo..., s. 7; idem, Lublin w okresie wyzwolenia (22-31 lipca 1944), „Rocznik Lubelski” 1966, t. IX, s. 354; idem, Lublin, lipiec '44, Lublin 1984, s. 46.

${ }^{20} \mathrm{Na}$ temat militarnych aspektów operacji „Burza” w Lublinie oraz innych rejonach Okręgu Lublin AK zob. np.: Z. Mańkowski, op. cit., s. 259-274; W. Wołczew, Przebieg realizacji planu „Burza” na Lubelszczyźnie, „Rocznik Lubelski” 1962, t. V, s. 213-234; T. Strzembosz, Burza na Lubelszczyźnie, „Biuletyn Informacyjny” 2004, t. XIV, nr 5, s. 7-18; I. Caban, Lublin w okresie..., s. 353-356; idem, Lublin, lipiec..., s. 31-57; P. Lisiewicz, op. cit., s. 230-243.

${ }^{21}$ Szanowny panie Stalin. Korespondencja pomiędzy Franklinem D. Rooseveltem a Iosifem W. Stalinem, oprac. S. Butler, tłum. M. Antosiewicz, Warszawa 2007, s. 286-287 (dok. nr 230); Dokumenty $i$ materiaty do historii..., s. 149-150 (dok. nr 70). 
Tym komunikatem sowiecki dyktator dał wyraźnie do zrozumienia, że przystapił do kolejnego etapu rozgrywania sprawy polskiej na arenie międzynarodowej. Od chwili ogłoszenia powstania uznawanego przez Sowietów PKWN nie wchodziła już w grę rekonstrukcja rządu polskiego w Londynie. Nowo utworzony komitet miał zatem stać się trzonem przyszłych władz polskich, którego platforma (wyłoniona w sposób kompromisowy) zostanie zaakceptowana przez wielką trójkę ${ }^{22}$.

Gdy AK i wojska sowieckie toczyły walkę o Lublin, do przejęcia władzy w województwie przygotowywała się także okręgowa delegatura rządu. 22 lipca zwołano naradę jej członków, w której trakcie debatowano nad sytuacją polityczną na Lubelszczyźnie. W tym czasie do siedziby delegatury przybyła łączniczka z Warszawy. Przekazała instrukcję, która nakazywała wyjście z konspiracji w wypadku wkroczenia do miasta Armii Czerwonej i rozpoczęcie normalnego funkcjonowania całej administracji na terenie województwa ${ }^{23}$. Celem koordynacji działań zapewniono sobie wymianę informacji między kierownictwem delegatury a ppłk. Kazimierzem Tumidajskim, dowódcą Okręgu Lublin AK. Była ona realizowana przez oddelegowanego oficera łącznikowego. Otmar Poźniak, zastępca okręgowego delegata, zredagował tekst obwieszczenia o przejęciu władzy do mieszkańców województwa. Przygotowano również zarządzenia w dziedzinie bezpieczeństwa wewnętrznego, ochrony zbiorów, a także aprowizacji i zaopatrzenia ludności. Projekty dokumentów zostały przekazane do drukarni ${ }^{24}$.

Ujmujemy ster odradzającego się Państwa we własne ręce - napisano w obwieszczeniu - bo nikt obcy nie może nas zastapić w sprawowaniu władzy w Ojczyźnie naszej. Z polecenia Rządu Rzeczypospolitej obejmuję z dniem dzisiejszym w[ładz]ę na terenie województwa lubelskiego. Od wszystkich żądam posłuchu zarządzeniom moim i podległych mi organów. Kierownicy cywilnych instytucji użyteczności publicznej zostają mi podporządkowani automatycznie i winni zgłosić się po dyrektywy. Wszelkie poczynania, odnoszące się do akcji zbrojnej, są podporządkowane rozkazom komendanta okręgu wojskowego Armii Krajowej ${ }^{25}$.

${ }^{22}$ K. Kersten, Dyplomacja polska w poszukiwaniu kompromisu polsko-sowieckiego (kwiecień-listopad 1944), w: Historia dyplomacji polskiej, t. V, red. W. Michowicz, Warszawa 1999, s. 524.

${ }^{23}$ Delegat Rządu na Kraj Jan Stanisław Jankowski podjął decyzję o ujawnieniu się administracji na przełomie czerwca i lipca 1944 r. Zob. Armia Krajowa w dokumentach..., s. 527 (dok. nr 659). Na konieczność dekonspiracji zwrócono uwagę również w trakcie obrad Komisji Głównej Rady Jedności Narodowej 5 VII 1944 r. Zob. W. Grabowski, Rada Jedności Narodowej - parlament Polskiego Państwa Podziemnego, „Pamięć i Sprawiedliwość” 2002, nr 2 (2), s. 74.

${ }^{24}$ Biblioteka Jagiellońska w Krakowie (dalej: BJ), Archiwum Jerzego Polaczka, przyb. 436, W. Cholewa, Wspomnienia z lipca 1944 [15 VII - 7 VIII 1944], Bełcząc 1959 (dalej: Wspomnienia Cholewy), mps, k. 12; J. Zych-Dolina, Pamiętny lipiec w Lublinie, „Kultura” 1950, nr 7-8 (33-34), s. 167-168.

${ }^{25}$ APL, ZWZ-AK Lublin, 303, Obwieszczenie urzędowe Delegata Rządu Rzeczypospolitej na województwo lubelskie, 25 VII 1944. 
Choć cytowany dokument był opatrzony podpisem: „Władysław Cholewa (w konspiracji: Łukasz Paśnik)”, jego treść nie została skonsultowana z okręgowym delegatem rządu. Kiedy projekt dokumentu przekazywano drukarzowi, Cholewa dopiero szykował się na wyjazd do Lublina. Od połowy lipca 1944 r. przebywał w Warszawie w związku z odprawą u wicepremiera Jana Stanisława Jankowskiego ${ }^{26}$.

22 lipca komendant wojewódzki Państwowego Korpusu Bezpieczeństwa (PKB) mjr Tadeusz Markiewicz wydał rozkaz do podległych mu funkcjonariuszy w sprawie oczekiwanego przejścia do jawnej działalności. Zawarł w nim szczegółowe wskazówki dotyczące umundurowania członków PKB, organizacji posterunków, zakresu współpracy z władzami administracyjnymi oraz sposobu pełnienia służby. Przewidywano także uruchomienie punktów, w których będzie dokonywana weryfikacja i rejestracja byłych funkcjonariuszy policji ${ }^{27}$.

Oprócz wojewódzkiej i powiatowej administracji ogólnej do przejęcia władzy przygotowywały się również niepodległościowe władze samorządowe. 24 lipca, działając w porozumieniu z Poźniakiem, obowiąki prezydenta miasta przeją wiceprezydent Marian Chojnowski ${ }^{28}$, pracujacy w czasie okupacji w wydziale opieki społecznej magistratu. Chojnowski poinformował o tym w trakcie posiedzenia, w którym brali udział naczelnicy komórek organizacyjnych urzędu oraz dyrektorzy przedsiębiorstw miejskich. Po naradzie wiceprezydent wydał zarządzenia organizacyjne i porządkowe, w których wezwał lublinian do zachowania spokoju i dyscypliny, porządkowania miejsc publicznych oraz odbudowy tkanki miejskiej. Jednocześnie wydał apel do obecnych w mieście urzędników o zgłoszenie się do pracy ${ }^{29}$.

Wyjście Okręgowej Delegatury Rządu (ODR) z konspiracji nastapiło 25 lipca $^{30}$. Wcześniej nie było to możliwe, gdyż duża część wojsk niemieckich

${ }^{26}$ BJ, Archiwum Jerzego Polaczka, przyb. 436, Wspomnienia Cholewy, k. 1-4.

${ }_{27}$ W. Grabowski, Rola administracji cywilnej $w$ akcji „Burza”, w: Administracja cywilna Polskiego Państwa Podziemnego i jej funkcje w okresie powstania warszawskiego, red. J. Czaputowicz, Warszawa 2011, s. 117-119 (aneks 1).

${ }^{28} \mathrm{Na}$ prezydenta miasta przewidziany był wówczas Roman Ślaski. Stanowiska tego jednak nie obją.

${ }^{29}$ Przez 7 dni bytem prezydentem Lublina, „Nowe Relacje”, 26 VII - 1 VIII 1990, nr 11, s. 1, 12; J. Marczuk, Prezydenci miasta Lublina 1918-1939, Lublin 1994, s. 101.

30 Struktura organizacyjna ujawnionej ODR przedstawiała się następująco: delegat - Władysław Cholewa, zastępca delegata - Otmar Poźniak, Wydział Administracji (naczelnik - Stefan Wendorff), Wydział Bezpieczeństwa (Józef Dolina), Wydział Samorządu (Piotr Typiak), Wydział Rolnictwa (Kazimierz Woyno), Wydział Opieki Społecznej (Saturnin Osiński), Wydział Zdrowia Publicznego (Jan Danielski), Wydział Szkolnictwa (Jan Odroń), Wydział Prasy i Informacji (Stanisław Pliszczyński), Wydział Skarbu (Kazimierz Stalewski), Wydział Przemysłowy (nie obsadzono stanowiska naczelnika). Cholewa wyznaczył również dyrektorów i kierowników instytucji publicznych oraz społecznych, a także państwowych zakładów przemysłowych. Zob. Ł. Kijek, Rzqdy Okręgowej Delegatury Rzqdu $R P$ w Lublinie, http://teatrnn.pl/leksykon/artykuly/rzady-okregowej-delegatury-rzadu-rpw-lublinie/ (dostęp: 15 V 2018). 
wróciła do miasta ze względu na akcje bojowe AK prowadzone na głównych drogach ich ewakuacji. Na siedzibę delegatury wyznaczono budynek Sądu Apelacyjnego (dziś gmach Sądu Okręgowego) mieszczący się przy ul. Krakowskie Przedmieście 43. W momencie, gdy trwała uroczystość wywieszenia flagi państwowej na budynku delegatury, do Lublina przybył Cholewa i rozpoczą swoje oficjalne urzędowanie. W tym czasie do władz wojewódzkich zaczęły napływać liczne delegacje oraz zgłoszenia od lokalnych instytucji, których funkcjonowanie przerwał wybuch wojny ${ }^{31}$.

Wieczorem na murach Lublina rozplakatowano obwieszczenie urzędowe delegatury o przejęciu władzy ${ }^{32}$. Upubliczniono także trzy zarządzenia. W pierwszym wezwano piekarzy, masarzy i sklepikarzy do zaopatrzenia ludności w żywność, w drugim - pracowników służb komunalnych, wodociagów, elektrowni i gazowni do uruchomienia zakładów, a w trzecim - dozorców i mieszkańców Lublina do oczyszczania miasta z martwych koni, gdyż zaniechania w tym zakresie mogły doprowadzić do wybuchu epidemii ${ }^{33}$.

Swoje jawne funkcjonowanie rozpoczęły także akowska komenda okręgu (mieściła się na Starym Mieście przy ul. Złotej 6), komenda miasta (ul. Górna 4), a także punkty werbunkowe ${ }^{34}$. W okolicach Krzczonowa zorganizowano, na wypadek aresztowań przez komunistów, rezerwową i zakonspirowaną Komendę Okręgu Lublin AK, na której czele stał ppłk Franciszek Żak ${ }^{35}$.

Wraz z dekonspiracją ODR w Lublinie ujawniły się również podległe struktury terenowe. 25 lipca w Biłgoraju kontakt z Sowietami nawiązał powiatowy delegat rządu Bronisław Mazurek ${ }^{36}$. Tego samego dnia w Zamościu, na krótko przed pojawieniem się czerwonoarmistów, jawną działalność rozpoczą

${ }^{31}$ J. Zych-Dolina, op. cit., s. 169.

${ }^{32}$ BJ, Archiwum Jerzego Polaczka, przyb. 436, Wspomnienia Cholewy, k. 13.

${ }^{33}$ J. Jachymek, Wtadystaw Cholewa (1892-1962). Ludowiec wzorowy, w: M. Mazurek, Wtadystaw Cholewa. Delegat Rzadu Londyńskiego na województwo lubelskie. Sybirak. Biografia, Czemierniki 2012, s. VI. Duża liczba martwych koni i zniszczonych taborów ciaggnęła się od ul. 3 Maja, przez Krakowskie Przedmieście i Aleje Racławickie, aż do rogatek miasta. Zob. Ośrodek Brama Grodzka - Teatr NN w Lublinie (dalej: OBG-TNN), Relacja Macieja Paprockiego z 23 VII 2012 r., http://teatrnn.pl/historiamowiona/swiadek/ Paprocki\%2C_Maciej_\%281931-_\%29?tar=43476 (dostęp: 20 V 2018); ibidem, Relacja Janusza Winiarskiego z 19 IV 2010 r., http://teatrnn.pl/historiamowiona/swiadek/Winiarski\%2C_Janusz\%2C_Andrzej_\%281933-2012\%29 (dostęp: 20 V 2018); A. Kasperska, Lublin 44: To byt tragiczny widok, „Kurier Lubelski”, 2 VIII 2012, nr 179, s. 6.

34 Jeden z punktów werbunkowych zlokalizowany był na ul. Marii Skłodowskiej-Curie. Podstawowy wymóg wstapienia do AK stanowiło posiadanie własnej broni. Zob. OBG-TNN, Relacja Stanisława Szpikowskiego z 7 V 2002 r., http://biblioteka.teatrnn.pl/dlibra/dlibra/ doccontent?id=42627\&dirids=1 (dostęp: $20 \mathrm{~V} 2018$ ).

35 A. Kister, Plany powstania powszechnego i operacji „Burza” na Lubelszczyźnie, 1943-1944, „Przegląd Historyczno-Wojskowy” 2003, nr 3, s. 148; I. Caban, Lublin w okresie..., s. 360.

36 J. Markiewicz, Powiatowa Delegatura Rzqdu Rzeczypospolitej Polskiej w Biłgoraju 29 VII 1944 - 8 VII 1944 r. (Próba zarysu $i$ analizy), w: Nad Tanwia $i$ Łada. Przyczynki do historii i kultury Ziemi Bitgorajskiej, Biłgoraj 2006, s. 43. 
delegat rządu Antoni Wiącek ${ }^{37}$. Jan Makaruk, delegat powiatowy na Biała Podlaska, po zajęciu przez Sowietów miasta 26 lipca nie zdecydował się na ujawnienie. W swoich wspomnieniach wskazuje, że nie otrzymał stosownych instrukcji od władz wojewódzkich. Przystapił natomiast do współorganizacji magistratu $^{38}$. 26 lipca ujawnił się również delegat rządu na powiat lubelski, Jan Chmielewski. Poinformował o tym miejscową ludność, wydając ogłoszenie urzędowe ${ }^{39}$.

25 lipca w godzinach popołudniowych do Lublina wkroczył oddział Armii Ludowej (AL) dowodzony przez Grzegorza Korczyńskiego ${ }^{40}$. Wraz z alowcami przybyli m.in. Bronisława Czarnotówna oraz Władysław Kuszyk, podajacy się za członków Wojewódzkiej Rady Narodowej (WRN) ${ }^{41}$. W mieście zjawiła się także grupa operacyjna Edwarda Ochaba, pełnomocnika Rady Wojennej 1 Armii Polskiej. Składało się na nią 152 oficerów i podoficerów, których zadaniem było przygotowanie miasta do przyjęcia berlingowców. W Lublinie pojawili się również działacze komunistyczni, którymi kierował Zygmunt Kratko. Ich zadaniem było przygotowanie siedziby pod urzędowanie PKWN. Na budynek komitetu wyznaczono Pałac Morskich (obecnie Krajowa Szkoła Sądownictwa i Prokuratury) stojący naprzeciwko gmachu ODR. Swoją działalność rozwinęła także grupa propagandzistów i agitatorów Mieczysława Wagrowskiego. Nawiązali kontakt z miejscowymi działaczami Polskiej Partii Robotniczej (PPR) i sympatykami komunizmu, a także prowadzili prosowiecka indoktrynację poprzez proste zabiegi socjotechniczne, takie jak organizacja wieców i zebrań, kolportaż prasy czy rozwieszanie plakatów ${ }^{42}$. Po południu przybyły kolejne grupy AL. Józef Dolina podaje, iż oddziały te miały wkraczać do Lublina kilka razy „odpowiednio przegrupowane i zmienione nieco zewnętrznie", chcąc zamanifestować przed miejscową ludnościa, a przede wszystkim przed delegaturą rządu i AK swoją siłę ${ }^{43}$.

${ }^{37}$ M. Łochowski, Dziesięć dni Antoniego Wiacka. Działalność Powiatowej Delegatury Rzqdu RP w Zamościu 25 lipca - 3 sierpnia 1944 roku, w: Zimowa Szkoła Historii Najnowszej 2016. Referaty, red. M. Przeperski, Ł. Kamiński, Warszawa 2017, s. 41-42.

${ }^{38}$ Miejska Biblioteka Publiczna w Białej Podlaskiej (dalej: MBP Biała Podlaska), Zbiory Jana Makaruka, Brulion protokołu zebrania Komitetu Obywatelskiego m. Biała Podlaska, 27 VII 1944; ibidem, J. Makaruk, „Byłem delegatem rządu na powiat Biała Podlaska”, mps, Warszawa 1982, k. 30-31.

${ }^{39}$ W. Grabowski, Polska Tajna Administracja Cywilna 1940-1945, Warszawa 2003, s. 383.

${ }^{40} 26$ lipca większość członków grupy Korczyńskiego utworzyła Lubelską Obwodową Komendę Milicji Obywatelskiej. Tego samego dnia do miasta przybyły również kolejne oddziały AL (Gustawa Bolkowiaka, Bolesława Kowalskiego i Edwarda Gronczewskiego). Zob. J. Romanek, Milicja Obywatelska, w: Dzieje Lubelszczyzny..., s. 228; T. Chabros, Kronika wydarzeń w Lublinie 21 VII 1944 - 1 II 1945, Lublin 1974, s. 20.

${ }^{41}$ W. Kuszyk, S. Szczepański, Pierwsze dni Wojewódzkiej Rady Narodowej w Lublinie (lipiec 1944), oprac. I. Caban, „Rocznik Lubelski” 1964, t. VII, s. 195-198.

${ }^{42}$ T. Żenczykowski, op. cit., s. 23; T. Chabros, op. cit., s. 18-19.

${ }^{43}$ J. Zych-Dolina, op. cit., s. 169-170. 
Centralna prasa rządowego podziemia zareagowała na komunikat o powołaniu PKWN dopiero 25 lipca. Wiadomość ta nie była w żaden sposób skomentowana i miała charakter informacyjny. Opierając się na doniesieniach Radiostacji im. Tadeusza Kościuszki, a także posiłkując się wydanym 23 lipca pierwszym numerem „Rzeczpospolitej”44, podano pełny skład komitetu. Dopiero w kolejnych dniach pojawiły się artykuły prasowe, które wskazywały, czym w istocie jest nowo utworzony organ administracyjny komunistów. Jak zauważa Karol Sacewicz, „Pisma konspiracyjne popełniały pewien błąd, przyjmowały mianowicie komunistyczna, oficjalną wersję utworzenia PKWN za pewnik" ${ }^{45}$.

Na wieść o powstaniu PKWN rząd polski w Londynie zareagował dopiero 25 lipca, wydając komunikat za pośrednictwem Polskiej Agencji Telegraficznej. Potępił w nim komunistów, określając ich mianem „garstki uzurpatorów”, która narzuca polskim obywatelom swoje „kierownictwo polityczne”46. Tego samego dnia minister spraw zagranicznych Tadeusz Romer wystosował do Churchilla memoriał. Czytamy w nim:

Komitet został utworzony na terytorium okupowanym przez wojska radzieckie. Jego utworzenie miało więc miejsce za wiedzą radzieckich władz okupacyjnych. Ponadto ogłoszenie komunikatu [o powołaniu PKWN - M.Ł.] przez oficjalne radio radzieckie wskazywałoby, że Rząd Radziecki popiera ten Komitet, mimo iż żadna formalna enuncjacja kompetentnych czynników Związku Radzieckiego nie miała dotąd miejsca w tej sprawie. [...] Prawda jest, że Komitet nie przybrał jeszcze dotąd tytułu Rządu, ale jego organizacja jest kopią normalnego rządu ${ }^{47}$.

W dalszej części dokumentu wyrażono obawę, że PKWN będzie dążył do zniszczenia polskiego podziemia rządowego oraz zacznie wprowadzanie własnych reform społecznych i politycznych. Słusznie także przewidywano - jak pokazał dalszy bieg wydarzeń - że komuniści rozpoczną tworzenie „lokalnych komitetów administracyjnych”, własnego sądownictwa oraz milicji obywatelskiej ${ }^{48}$.

44 „Rzeczpospolita” była organem prasowym PKWN. Pierwszy numer został wydany w Chełmie. Znajdował się w nim m.in. dekret o powołaniu PKWN przez KRN, a także tekst manifestu lipcowego. Więcej na temat prasy z okresu funkcjonowania PKWN zob. np.: J. Myśliński, Prasa $w$ Polsce Ludowej, w: J. Łojek, J. Myśliński, W. Władyka, Dzieje prasy polskiej, Warszawa 1998, s. 159-160.

${ }^{45}$ K. Sacewicz, Centralna prasa Polski Podziemnej wobec komunistów polskich 1939-1945, Warszawa 2009, s. 335-336.

${ }^{46}$ A. Skrzypek, Mechanizmy uzależnienia. Stosunki polsko-radzieckie 1944-1957, Pułtusk 2002, s. 42; Prawdziwa historia Polaków. Ilustrowane wypisy źródtowe 1939-1945, t. III: 1944-1945, oprac. D. Baliszewski, A.K. Kunert, Warszawa 2000, s. 1802 (dok. nr 1562).

${ }^{47}$ Represje NKWD wobec żotnierzy podziemnego Państwa Polskiego w latach 1944-45. Wybór źródet, oprac. F. Gryciuk, P. Matusak, t. I, Siedlce 1995, s. 97 (dok. nr 42).

${ }^{48}$ Ibidem, s. 98-99. 
Warto zwrócić uwagę na to, że również najwyżsi dygnitarze III Rzeszy dobrze zdawali sobie sprawę z charakteru powoływanego przez Stalina komitetu i kształtującej się na ziemiach polskich sytuacji.

Politycznie jest rzeczą interesująca - napisał w dzienniku Joseph Goebbels - że teraz zainstalował się w Moskwie polski komitet narodowy [...]. Polscy emigranci w Londynie wrzeszcza, że chodzi tu wyłącznie o lewicowych intelektualistów. Ja jednak sądzę, że tej sprawie należy przypisać większe znaczenie. Stalin podniesie tych tak zwanych lewicowych intelektualistów, którzy w rzeczywistości są bolszewikami, do rangi polskiego rządu, a polski rząd emigracyjny w Londynie i także rząd brytyjski odejdą z kwitkiem ${ }^{49}$.

Temat ten poruszono także 26 VII 1944 r. w trakcie posiedzenia kierowników wydziałów rządu Generalnego Gubernatorstwa. „W Chełmie został już z inicjatywy sowieckiej utworzony polski rząd [...]. Nie jest on bynajmniej zorganizowany na modłę sowiecka, lecz zamaskowany w zupełnie naturalny sposób przy pomocy takich środków, jak polska flaga, polskie pieśni itd. Ten tzw. rząd będzie na pewno próbował prowadzić intensywną propagandę na terenach znajdujących się jeszcze w naszym ręku" ${ }^{50}$.

Jeszcze przed wylotem przedstawicieli PKWN z Moskwy na Lubelszczyznę zawarto dwa ważne porozumienia między polskimi komunistami a Sowietami. 26 lipca podpisano umowę regulującą stosunki między obiema stronami po wkroczeniu Armii Czerwonej na - uznawanym przez władze sowieckie - terytorium Polski. „W strefie działań wojennych na terytorium Polski - napisano w dokumencie - po wkroczeniu wojsk radzieckich władza najwyższa i odpowiedzialność we wszystkich sprawach dotyczących prowadzenia wojny, [...] koncentruje się w ręku wodza naczelnego wojsk radzieckich" "51. Tym samym Sowieci zapewnili sobie formalną dominację nad polskimi komunistami. Natomiast 27 lipca „uregulowano kwestię granicy państwowej”, przyjmując na wschodzie za jej podstawę linię Curzona. Strony porozumienia pozwoliły sobie również dokonać wstępnego podziału ziem niemieckich (łącznie z anektowanym Gdańskiem). W ramach komunistycznej Polski miały się znaleźć Prusy Wschodnie (bez Królewca), Gdańsk, Pomorze Zachodnie (ze Szczecinem), ziemia lubuska, Opolszczyzna oraz Dolny Ślask ${ }^{52}$.

${ }^{49}$ J. Goebbels, Dzienniki 1943-1945, wybór, tłum., wstęp i oprac. E. Król, t. III, Warszawa 2014, s. 367.

${ }^{50}$ Okupacja i ruch oporu $w$ dzienniku Hansa Franka 1939-1945, wybór i oprac. L. Dobroszycki i in., tłum. D. Dąbrowska, M. Tomala, t. II, Warszawa 1972, s. 531-532 (dok. nr 224).

${ }^{51}$ Dokumenty i materiaty do historii..., s. 156 (dok. nr 75). Poprzez „strefę działań wojennych” należy rozumieć tę część terytorium Polski po zachodniej stronie Bugu, która została zajęta przez Armię Czerwona. Zob. J. Wrona, Lublin w okresie Polskiego Komitetu Wyzwolenia Narodowego, w: Lublin $w$ dziejach i kulturze Polski, red. T. Radzik, A. Witusik, Lublin 1997, s. 368.

${ }^{52}$ Dokumenty i materiaty do historii..., s. 158-159 (dok. nr 76). 
26 lipca do Lublina wkroczyły kolumny marszowe 1 Armii Polskiej. Zorganizowana została uroczysta defilada z udziałem berlingowców i członków AL z flagami państwowymi i orkiestrą ${ }^{53}$. Na chodnikach zgromadził się tłum mieszkańców. Szczególnie serdecznie, kwiatami i wiwatami, przyjmowane były pierwsze oddziały biorace udział w defiladzie. Po pewnym czasie jednak liczba świętujących ludzi zaczęła maleć. Osłabł również ich entuzjazm. Było to spowodowane faktem, iż znaczna część mieszkańców zidentyfikowała niektórych żołnierzy (szczególnie tych, którzy należeli do korpusu oficerskiego) jako Sowietów ${ }^{54}$.

Przykre dla mnie było - wspominał Józef Sadurski - jak chcieliśmy z siostrą powitać grupę Polaków, podoficerów, oficerów, narwaliśmy kwiatów z ogrodu, podbiegliśmy do tych żołnierzy, a z nich żaden po polsku nie mówił, tylko mundury były polskie. Później przestałem się dziwić, kilka dni po wkroczeniu tak zwanych przyjaciół, szedłem Lubartowska, i szedł jeden żołnierz z góry w rogatywce, a drugi z dołu i jeden do drugiego powiedział „Szto i tiebie dali eta kuricu?” [,Więc i tobie dali tę kurę?" - mowa o polskim godle państwowym - M.Ł.. ${ }^{55}$.

Tego dnia miała miejsce pierwsza próba odsunięcia okręowej delegatury rządu od władzy. Około godz. 10.00 do siedziby administracji wojewódzkiej

5318 XII 1944 r. brytyjski producent filmów dokumentalnych i kronik filmowych British Pathé zrealizował, na podstawie sowieckich materiałów, film dokumentalny pt. The Tragic City Of Lublin. Znajdują się w nim sceny, w których ukazano m.in. walki o miasto, zniszczenia Lublina, ciała więźniów zabitych na Zamku Lubelskim oraz uroczystości ku czci pomordowanych. Ważną częścią filmu jest również defilada, w której brali udział Armia Czerwona, LWP oraz „partyzanci” (ang. guerillas) - członkowie AL. Film dostępny pod adresem: https://www.britishpathe.com/video/the-tragic-city-of-lublin (dostęp: $11 \mathrm{~V}$ 2018).

${ }^{54}$ Armia Berlinga była całkowicie podporządkowana władzom sowieckim. We wszystkich dowództwach do poziomu pułku obecni byli czerwonoarmiści pełniący funkcję doradców wojskowych. Ochronę kontrwywiadowczą zapewniał Główny Zarząd Informacji, którego korpus oficerski składał się wyłącznie z Sowietów. Zob. E. Kospath-Pawłowski, Chwała i zdrada. Wojsko Polskie na Wschodzie 1943-45, Warszawa 2010, s. 129. Przed wkroczeniem 1 AP na tereny uznawane przez komunistów za ziemie polskie czyniono starania o to, aby oddelegowani do jednostek polskich oficerowie Armii Czerwonej zintegrowali się z resztą żołnierzy. W tym celu w oddziałach prowadzone były wykłady poświęcone Polsce oraz kursy języka polskiego. Obawiano się, że jeśli wyjdzie na jaw okoliczność służby czerwonoarmistów w LWP, zostanie to wykorzystane przez „wrogów demokracji do jątrzenia części ludności polskiej”. Zob. Wojsko Polskie na froncie wschodnim 1943-1945. Wybór materiałów źródłowych, wybór i oprac. C. Grzelak, H. Stańczyk, S. Zwoliński, Warszawa 1994, s. 48 (dok. nr 29). Po wielu latach do kwestii sowieckiego dowództwa w Armii Berlinga odniosła się Wasilewska. W jednym z wywiadów oświadczyła, że polskich kadr oficerskich nie było wówczas na terenie ZSRS, a nawet gdyby się pojawiły, to i tak zostałyby „zdyskwalifikowane kilkuletnią przerwą w wykształceniu wojskowym”. Zob. Wspomnienia Wandy Wasilewskiej, „Archiwum Ruchu Robotniczego” 1982, t. VII, s. 388.

${ }_{55}$ OBG-TNN, Relacja Józefa Sadurskiego z 1 IX 2010 r., http://biblioteka.teatrnn.pl/dlibra/ dlibra/doccontent?id=47211\&dirids=1 (dostęp: $20 \mathrm{~V}$ 2018). O podobnych sytuacjach podczas powitania 1 AP wspominał Józef Dolina. Zob. J. Zych-Dolina, op. cit., s. 170. 
przybył wysłannik Korczyńskiego, który podczas krótkiej rozmowy z Cholewa nakazał likwidacje jego biura. Delegat rządu stanowczo odmówił. Świadkami rozmowy byli interesanci oczekujący na załatwienie swych spraw, którzy, jak wspominał Cholewa, „śmiechem zareagowali na pogróżki zastępcy pana pułkownika Korczyńskiego" ${ }^{56}$.

Poważny problem na obszarach opuszczonych przez Niemców stanowiła grabież mienia pozostającego bez opieki lub nadzoru. Aby zapobiec szabrownictwu oraz utrzymać porządek w mieście, delegatura wydała 27 lipca stosowne rozporządzenie. Wezwano w nim ludność do podporządkowania się poleceniom i zarządzeniom władz wojewódzkich. Osoby dopuszczające się zabójstw, gwałtów, kradzieży z bronią w ręku miały zostać postawione przed sądami specjalnymi. Poinformowano również o powołaniu „organów służby bezpieczeństwa”, które „pełnią na razie służbę bez jednolitego umundurowania, a jedyną oznaką ich funkcji jest opaska o barwach narodowych z literami P.K.B. i odpowiednia legitymacja”. Zobowiązano mieszkańców do zabezpieczenia mienia opuszczonego przez władze okupacyjne, a przedsiębiorcy mieli niezwłocznie uruchomić swoje zakłady. Rozporządzenie zawierało ponadto zapisy wymierzone w Niemców, osoby pochodzenia niemieckiego, a także „inne narodowości, które w czasie okupacji niemieckiej lub przedtym działały na szkodę Narodu Polskiego lub w czasie obecnej wojny na szkodę mocarstw sprzymierzonych”. Osoby te miały zostać zatrzymane, a ich majątek „zabezpieczony" ${ }^{57}$.

27 lipca ustanowiona została komenda miasta LWP, na której czele staną gen. Jan Mierzycan. Swoją działalność rozpoczęły także komenda garnizonu lubelskiego Armii Czerwonej pod zarządem gen. Nikołaja Trufanowa oraz komenda wojenna gen. Iwana Senczyłły. Sowieckie władze wojskowe miały swoja siedzibę w budynkach przy ul. Krakowskie Przedmieście 58-62. Zorganizowana została również komenda NKWD przy ul. Chopina 18. Główna rolę w mieście odgrywał gen. Władimir Kołpakczi - dowódca 69 Armii $^{58}$.

Tego dnia do siedziby delegatury przybyła delegacja sowiecka, która przyją Dolina. Złożono podziękowania za pracę polskiej administracji - zapewnienie spokoju i porządku na terenie województwa, aprowizację ludności, a przede wszystkim za zorganizowanie w czasie walk dodatkowych szpitali ${ }^{59}$. Z kolei mjr Markiewicz odbył rozmowę z gen. Berlingiem. Dowódca 1 Armii Polskiej zażądał, aby Cholewa zjawił się w jego biurze celem podjęcia pertraktacji. Komendant PKB odmówił przekazania tej informacji i stwierdził, że to Cholewa

${ }_{56}$ BJ, Archiwum Jerzego Polaczka, przyb. 436, Wspomnienia Cholewy, k. 14.

57 APL, ZWZ-AK Lublin, 304, Rozporządzenie w sprawie bezpieczeństwa i porządku publicznego, 26 VII 1944. Wiadomo, iż podobny antyniemiecki dokument został wydany również przez powiatowego delegata rządu w Zamościu. Zob. Muzeum Zamojskie w Zamościu, Archiwum historyczne, nr inw. 235, Zarządzenie nr 3 Delegata Powiatowego Rządu Polskiego J. Sandomierskiego, 27 VII 1944.

${ }^{58}$ T. Żenczykowski, op. cit., s. 35; T. Chabros, op. cit., s. 21.

${ }^{59}$ J. Zych-Dolina, op. cit., s. 173. 
jest gospodarzem na tym terenie, stąd nie może „składać wizyt gościom choćby nimi byli generałowie”. Do spotkania ostatecznie nie doszło, mimo iż Berling zgodził się złożyć wizytę w siedzibie władz wojewódzkich o godz. 12.00. W nocy oddział LWP zajał budynek delegatury i obezwładnił strzegacych go funkcjonariuszy PKB. Siedziba urzędu została przeniesiona następnego dnia do budynku przy ul. Chopina 7 , gdzie mieściła się komenda $\mathrm{PKB}^{60}$. 28 lipca wydana została odezwa przez gen. Berlinga i gen. Aleksandra Zawadzkiego, w której wezwano AK i BCh do „niezwłocznego wstapienia do Wojska Polskiego". Jednocześnie zapowiedziano, że formacje zbrojne, które nie podporządkują się zarządzeniu, zostaną rozbrojone ${ }^{61}$. W dniu tym miała miejsce ważna rozmowa między komendantem okręgu lubelskiego AK a sowieckim dowództwem. Generał Kołpakczi zażądał od ppłk. Tumidajskiego podjęcia decyzji, czy podlegli mu żołnierze mają zostać rozbrojeni, czy też zostana wcieleni do LWP. Okręgowy dowódca AK zdecydował się na rozbrojenie ${ }^{62}$. Po południu oficer łącznikowy poinformował delegaturę o wynikach rozmów ${ }^{63}$.

Po rozbrojeniu AK komuniści planowali zając się administracją wojewódzka podległa polskiemu rządowi. 29 lipca Cholewa, Dolina oraz mjr Markiewicz zostali zaproszeni przez kapitana Armii Czerwonej do siedziby sowieckiego dowództwa. Czekało na nich kilkunastu oficerów Armii Czerwonej oraz porucznik z LWP, pełniący funkcję tłumacza. „Przyjęto nas - wspominał Dolina - z honorami i przesadna aż grzecznością" ${ }^{64}$. Każdy gość wchodził do gabinetu pojedynczo. Generał Kołpakczi w trakcie rozmów dał do zrozumienia, że nie może dopuścić, aby na zapleczu frontu istniały dwie równoległe władze cywilne z uzbrojonymi organami bezpieczeństwa. Delegat rządu zaczął wyjaśniać, iż PKB pomaga w utrzymaniu porządku i odciąża Armię Czerwona, aby ta mogła skupić się na walce z Niemcami. Na to dowódca odrzekł, że odtąd za bezpieczeństwo w mieście odpowiedzialni będą wyłącznie Sowieci. Pod naciskiem oficerów Armii Czerwonej Cholewa zdecydował się nie stawiać oporu i podpisał odpowiednie dokumenty. Po nim swoje podpisy złożyli Dolina i mjr Markiewicz ${ }^{65}$. Wkrótce nastapiły w Lublinie pierwsze aresztowania. Opis rozbrajania funkcjonariuszy PKB podaje Edward Gorajewski: „Widziałem rozbrajanie tej żandarmerii, która pilnowała i która była do dyspozycji tej delegatury. Widziałem, że podchodziło 5-6 takich do jednego żołnierza, i od

${ }^{60}$ BJ, Archiwum Jerzego Polaczka, przyb. 436, Wspomnienia Cholewy, k. 16; J. Zych-Dolina, op. cit., s. 175.

${ }^{61}$ Prawdziwa historia Polaków..., s. 1830 (dok. nr 1586).

${ }^{62}$ Armia Krajowa $w$ dokumentach..., s. 592-593 (dok. nr 697). Mimo rozbrojenia ppłk Tumidajski opowiedział się w depeszy wysłanej do komendanta głównego AK za dalszym ujawnianiem konspiracji zbrojnej. Zob. ibidem, s. 593 (dok. nr 698).

${ }^{63}$ J. Zych-Dolina, op. cit., s. 176.

${ }^{64}$ Ibidem, s. 177.

${ }^{65}$ BJ, Archiwum Jerzego Polaczka, przyb. 436, Wspomnienia Cholewy, k. 17-18; J. Zych-Dolina, op. cit., s. 178. 
razu zabierali mu magazynek z pepeszy, aresztowali i prowadzili na ulicę Chopina 7, gdzie była Komenda Miasta NKWD"66.

Z biegiem czasu aktywność komunistów jeszcze bardziej ograniczyła funkcjonowanie delegatury rządu. Drukarnie, działając pod presją członków PKWN, zaczęły odmawiać powielania dekretów i zarządzeń władz wojewódzkich. Rekwirowano również dotychczas wydane zarządzenia oraz pieczęcie urzędowe $^{67}$. Powyższe zabiegi poważnie ograniczyły wpływ informacyjny i propagandowy ODR na społeczeństwo.

$\mathrm{Na} 30$ lipca komuniści zaplanowali przejęcie władzy w samorządzie. Tadeusz Kadura i Stanisław Szczepański, w towarzystwie dowódcy oddziału AL, Gustawa Bolkowiaka, wkroczyli do magistratu podczas zebrania kierownictwa. Używając przemocy, zmusili Chojnowskiego do zaprzestania działalności. Wraz z nim odeszli wszyscy naczelnicy wydziałów. Prezydentem miasta z ramienia WRN został Kadura ${ }^{68}$. W nocy zlikwidowano siedzibę delegatury i PKB. Tym razem budynek został zajęty nie przez berlingowców, a NKWD ${ }^{69}$.

31 lipca nad ranem do sowieckiego dowództwa wezwano delegata rządu, jego zastępcę oraz kierownika wydziału bezpieczeństwa. W wyniku chwilowej nieobecności w mieście zastępcy delegata jako trzeci oddelegowany został naczelnik wydziału administracji i doradca organizacyjny, Stefan Wendorff, ze względu na dobrą znajomość języka rosyjskiego. Przed przystapieniem do zasadniczych rozmów polscy przedstawiciele musieli ustosunkować się do zarzutów sowieckich oficerów, dotyczących ukrywania broni przez PKB i zbyt wolno prowadzonej akcji rozbrojenia. Wkrótce w gabinecie pojawił się wysoki przedstawiciel NKWD Bielajew ${ }^{70}$, powiadamiając o rzeczywistym powodzie wizyty. Oznajmił, iż członkowie władz komunistycznych chcą mówić z przedstawicielami ODR i nakazał odprowadzenie Cholewy, Doliny oraz Wendorffa do pokoju, w którym miało nastapić spotkanie z niedawno przybyłymi do Lublina: Bolesławem Drobnerem (kierownik Resortu Pracy, Opieki Społecznej i Zdrowia PKWN), Hilarym Mincem (pełnomocnik Centralnego Biura Komunistów Polskich) i Stanisławem Kotkiem-Agroszewskim (kierownik Resortu Administracji Publicznej PKWN). Komuniści próbowali przekonać przedstawicieli delegatury, by wraz z podległym aparatem urzędniczym przeszli na ich stronę. Propozycja ta została odrzucona ${ }^{71}$.

${ }^{66}$ OBG-TNN, Relacja Edwarda Gorajewskiego z 17 VI 2005 r., http://biblioteka.teatrnn.pl/ dlibra/dlibra/docmetadata?id=35658\&from=publication (dostęp: $20 \mathrm{~V} 2018$ ).

${ }^{67}$ Archiwum Akt Nowych w Warszawie, Delegatura Rządu RP, 2287/4, Depesza „Paśnika” do Pełnomocnika Rządu, 29 VII 1944.

${ }^{68}$ Przez 7 dni..., s. 12; W. Kuszyk, S. Szczepański, op. cit., s. 210; G. Alef-Bolkowiak, Gorace dni, Warszawa 1971, s. 234.

${ }^{69}$ BJ, Archiwum Jerzego Polaczka, przyb. 436, Wspomnienia Cholewy, k. 20.

${ }^{70}$ Bielajew najprawdopodobniej miał stopień podpułkownika lub generała.

71 BJ, Archiwum Jerzego Polaczka, przyb. 436, Wspomnienia Cholewy, k. 20-22; J. Zych-Dolina, op. cit., s. 178-180. 
Po zakończonej rozmowie sowiecki oficer oznajmił, iż konieczne są dalsze pertraktacje, jednak tym razem z przedstawicielami PKWN w Chełmie. Po dotarciu na miejsce Cholewa wraz ze współpracownikami został najpierw skierowany do gabinetu gen. NKWD Gieorgija Żukowa. Oficer namawiał do nawiązania współpracy z komunistami, wyjaśniając, że rząd sowiecki nie uznaje władz polskich w Londynie, a jedynie PKWN. Dialog nie przyniósł oczekiwanych przez generała skutków, wobec czego odprowadzono przedstawicieli polskiej administracji do auta i wyruszono do gmachu Dyrekcji Kolei na spotkanie z Osóbką-Morawskim (przewodniczący PKWN i kierownik Resortu Spraw Zagranicznych) oraz Andrzejem Witosem (wiceprzewodniczacy PKWN oraz kierownik Resortu Rolnictwa i Reform Rolnych). Po raz kolejny powtórzono sugestie i namowy do współpracy w ramach komitetu ${ }^{72}$. Po pewnym czasie Dolina wiedząc, że dalsza rozmowa będzie bezcelowa, miał ja uciąć stwierdzeniem: „Zajmujecie sobie panowie zbyt dużo drogiego zapewne czasu. Jesteście góra, bo armia sowiecka pierwsza wkracza do Polski, - my bylibyśmy w lepszej jeszcze sytuacji - bo mielibyśmy za sobą i wolę społeczeństwa - gdyby to pierwsze wkraczały, np. od Bałkanów - armie zachodnich aliantów" 73 . Po spotkaniu przedstawiciele władz wojewódzkich zostali skierowani na krótką rozmowę do szefa bezpieki Stanisława Radkiewicza. Dialog dotyczył m.in. kwestii rozbrojenia AK. Radkiewicz twierdził, iż AK zwróciła tylko część posiadanej broni, resztę „melinując”. Poinformował również o planowanej mobilizacji, która miała „uspokoić teren”. Ponadto chciał, aby delegatura wydała obwieszczenie o zakończeniu działalności ${ }^{74}$.

1 sierpnia rano zorganizowano w Lublinie zebranie członków władz wojewódzkich. Brał w nim udział również ppłk Tumidajski. Ustalono, iż ze względu na powstałe okoliczności dalsza działalność jest bezcelowa. Londyn został powiadomiony o ustaleniach powziętych na spotkaniu drogą radiowa. Od 3 sierpnia lubelscy przedstawiciele PPP znajdowali się w siedzibie NKWD, gdzie poddano ich drobiazgowemu śledztwu. 6 sierpnia ppłk. Tumidajskiego, Cholewę, Poźniaka, Dolinę i Danielskiego przetransportowano do Świdnika,

72 BJ, Archiwum Jerzego Polaczka, przyb. 436, Wspomnienia Cholewy, k. 22-24; Armia Krajowa $w$ dokumentach..., s. 597 (dok. nr 706); J. Zych-Dolina, op. cit., s. 180-183.

${ }^{73}$ J. Zych-Dolina, op. cit., s. 183. Warto zwrócić uwagę na fakt, iż Osóbka-Morawski podał fałszywy przebieg rozmowy podczas spotkania premiera Mikołajczyka z członkami PKWN, które odbyło się w dniach 6-7 VIII 1944 r. Sparafrazował on następująco słowa, które miał wówczas rzekomo wypowiedzieć Cholewa: „Gdybyśmy byli przyszli pierwsi, to bylibyśmy góra, skoro jednak wy byliście pierwsi, to wy jesteście góra”. W zacytowanej wyżej wypowiedzi nie chodziło jednak o rzekome wcześniejsze ujawnienie się PKWN względem Okręgowej Delegatury Rządu, a fakt wkroczenia na ziemie polskie Armii Czerwonej przed wojskami zachodnich aliantów. Zob. Instytut Polski i Muzeum im. gen. Sikorskiego w Londynie, Akta Prezydium Rady Ministrów, PRM.Z.4, Brulion protokołów rozmów z Polskim Komitetem Wyzwolenia Narodowego przeprowadzonych w Moskwie w dniach 6 i 7 VIII 1944, [b.d.], k. 9.

${ }^{74}$ J. Zych-Dolina, op. cit., s. 183-184. 
a stamtąd droga lotniczą do Moskwy. Następnie więziono ich w obozach $\mathrm{NKWD}^{75}$. W podobnych okolicznościach, jak administracja szczebla wojewódzkiego, został pozbawiony władzy również powiatowy delegat w Zamościu ${ }^{76}$. Z kolei jego odpowiednik na powiat bialski po skontaktowaniu się $\mathrm{z}$ aparatem urzędniczym podległym PKWN przyjął nominację na powiatowego inspektora szkolnego ${ }^{77}$. Można przypuszczać, iż warunkiem rozpoczęcia pracy $\mathrm{w}$ sferze edukacji były dobrowolna rezygnacja $\mathrm{z}$ działalności w administracji rządowej i oddanie władzy w Białej Podlaskiej komunistom.

Po tych zajściach pozostający na wolności żołnierze lubelskiej AK i przedstawiciele ODR musieli ponownie zejść do konspiracji. Obowiązi delegata przeją Aleksy Bień. Odtąd głównym celem działalności pionu cywilnego PPP były podtrzymanie $\mathrm{w}$ społeczeństwie poczucia dalszego funkcjonowania legalnych władz polskich na emigracji i aktywność propagandowo-informacyjna. Podkreślano uzurpatorski charakter komunistycznych organów władzy ${ }^{78}$. Swoja działalność rozpoczął również zakonspirowany komendant okręgu ppłk Żak.

W nowej sytuacji trudno było się odnaleźć ludności województwa. Wejście Armii Czerwonej do miasta oznaczało przede wszystkim koniec funkcjonowania niemieckiego aparatu terroru i represji, co stanowiło powód powszechnej radości lublinian. Z czasem do działań Sowietów zaczęto podchodzić z coraz większą rezerwą i nieufnością. Długotrwałe przebywanie w obszarze działań wojennych oraz słaba aprowizacja oddziałów spowodowały, że kondycja fizyczna i psychiczna znakomitej większości czerwonoarmistów była zła ${ }^{79}$. Powyższe czynniki, a także brak dostatecznej kontroli ze strony przełożonych lub odpowiednich formacji wojskowych sprawiły, iż nasilały się ze strony Sowietów kradzieże (głównie żywności), rozboje, gwałty, a nawet zabójstwa ${ }^{80}$.

75 BJ, Archiwum Jerzego Polaczka, przyb. 436, Wspomnienia Cholewy, k. 25-29; T. Żenczykowski, op. cit., s. 38; J. Zych-Dolina, op. cit., s. 185-188. Szczegółowe dane dotyczące miejsc i czasu więzienia Cholewy, Poźniaka, Doliny i Danielskiego dostępne są m.in. w serwisie internetowym Indeks Represjonowanych, prowadzonym przez Instytut Pamięci Narodowej (http://indeksrepresjonowanych.pl [dostęp: 12 V 2018]). Informacje dotyczące skazania ppłk. Tumidajskiego zob. I. Caban, Ludzie Lubelskiego Okregu Armii Krajowej, Lublin 1995, s. 197-198.

${ }^{76}$ M. Łochowski, op. cit., s. 45; J. Markiewicz, op. cit., s. 45-46.

77 MBP Biała Podlaska, Zbiory Jana Makaruka, Zaświadczenie Kuratorium Okręgu Szkolnego Lubelskiego w Lublinie, 14 VIII 1944; Urząd do Spraw Kombatantów i Osób Represjonowanych w Warszawie, K3031036, Akta kombatanckie Jana Makaruka; J. Makaruk, op. cit., k. 35.

${ }^{78}$ P. Gawryszczak, Powstanie i upadek konspiracji antyniemieckiej $i$ antysowieckiej $w$ Inspektoracie Lublin, w: Podziemie zbrojne na Lubelszczyźnie wobec dwóch totalitaryzmów 1939-1956, red. S. Poleszak, A. Puławski, Warszawa 2002, s. 52.

79 OBG-TNN, Relacja Janusza Winiarskiego z 19 IV 2010 r., http://biblioteka.teatrnn.pl/ dlibra/dlibra/doccontent?id=39533\&dirids=1 (dostęp: $20 \mathrm{~V} \mathrm{2018);} \mathrm{ibidem,} \mathrm{Relacja} \mathrm{Jerzego}$ Szewczyka z 28 IV 2010 r., http://biblioteka.teatrnn.pl/dlibra/dlibra/doccontent?id=49354\&-dirids=1 (dostęp: $20 \mathrm{~V}$ 2018).

${ }^{80}$ A.L. Sowa, Od Drugiej do Trzeciej Rzeczypospolitej (1945-2001), Kraków 2001, s. 11. 
Przedstawiciele niektórych lewicujących grup politycznych i miejscowi komuniści od razu zaakceptowali urzędowanie PKWN i KRN. Podobnie postapiła część mieszkańców zwabiona hasłami o „sprawiedliwości społecznej”, „rządach ludowych”, „uspołecznionych środkach produkcji” czy powszechnym dobrobycie, upatrująca w zaangażowaniu się na rzecz komunistycznego aparatu urzędniczego podniesienia swojego statusu materialnego czy awansu społecznego ${ }^{81}$. Członkowie PKWN i rad narodowych publicznie nie głosili haseł komunistycznych. Starali się także omijać ważne, choć niewygodne, tematy (np. kwestię polskiej granicy wschodniej). Zdecydowanie najliczniej reprezentowani byli ludzie niechętni komunistom. PKWN traktowano z nieufnością ze względu na to, że nie stanowił emanacji krajowych sił politycznych, a jego rzeczywisty rodowód był aż nazbyt widoczny. Czarę goryczy przelało odkrycie, że długo wyczekiwane przez Polaków Wojsko Polskie przybyłe ze wschodu okazało się całkowicie podległe Moskwie.

W miejscu tym warto pokrótce odnieść się do historiografii doby PRL, poświęconej prezentowanemu zagadnieniu. Starała się ona utrwalić mit wytworzony $\mathrm{w}$ latach czterdziestych, jakoby na przełomie lipca i sierpnia 1944 r. funkcjonowała na obszarze województwa lubelskiego swego rodzaju dwuwładza. Pierwszym z ośrodków rządzących mieli być komuniści, chcący w założeniu uczynić ten teren - jak to niegdyś określił Adam Wendel - „kolebka władzy robotników i chłopów" 82 , a drugim - przedstawiciele terenowi rządu polskiego w Londynie. Podkreślano, opierając się na marksistowskiej interpretacji dziejów, iż przejęcie władzy przez komunistów nastapiło w drodze „rewolucji społecznej” i było efektem zwycięstwa „sił demokratycznych i mas pracujących” nad „burżuazją i obszarnikami”. Sugerowano, iż konfrontacja rozstrzygnęła się na gruncie polskim, bez udziału czynników z zewnątrz (rolę Sowietów ograniczano do walki przeciwko siłom zbrojnym III Rzeszy). W rzeczywistości omawiana konfrontacja nie była wynikiem wzmożonej rywalizacji poszczególnych klas (warstw) społecznych i stanowiących ich emanację ośrodków władzy, lecz efektem działań podjętych przez Stalina, majacych na celu podporządkowanie ziem polskich oraz zabezpieczenie interesów geopolitycznych Związku Sowieckiego w kończącej się wojnie. Marginalizowana przez historiografię PRL obecność Armii Czerwonej i NKWD na Lubelszczyźnie stanowiła kluczowy czynnik wpływający na sytuację polityczną w regionie.

${ }^{81}$ P. Gawryszczak, Powstanie i upadek konspiracji..., s. 52.

${ }^{82}$ A. Wendel, KRN i PKWN - pierwsze władze Polski Ludowej, „Rocznik Lubelski” 1959, t. II, s. 22. 


\section{Streszczenie}

Artykuł jest poświęcony wypadkom, jakie miały miejsce w Lublinie na przełomie lipca i sierpnia 1944 r. W tym czasie, ze względu na zbliżanie się Armii Czerwonej do miasta, zdecydowano się na ujawnianie struktur cywilnych Polskiego Państwa Podziemnego, którego głównym celem było objęcie władzy na opuszczonych przez Niemców terenach. Akcja ta miała być realizowana jednocześnie z wystapieniem zbrojnym Armii Krajowej w ramach operacji „Burza”. Do objęcia władzy na wyzwolonych spod okupacji niemieckiej ziemiach przygotowywali się również polscy komuniści wspierani przez Kreml. Początkowo starali się oni nakłonić przedstawicieli delegatury do ustapienia z zajmowanych stanowisk, a następnie, gdy nie przynosiło to skutku, zachęcali do podjęcia współpracy w ramach PKWN. Z czasem konflikt między dwoma ośrodkami politycznymi zaostrzył się. Po zaledwie kilku dniach jawnej działalności terenowi przedstawiciele władz emigracyjnych zostali aresztowani przez Sowietów i przetransportowani do ZSRS, gdzie trafili do obozów pod zarządem NKWD. Prezentowany artykuł stanowi próbę zrekonstruowania wydarzeń, jakie miały miejsce w Lublinie w okresie od ustapienia Niemców w połowie trzeciej dekady lipca do momentu aresztowania przedstawicieli lubelskiej AK i okręgowej delegatury rządu. Zaprezentowana została w szczególności działalność ujawnionych organów Polskiego Państwa Podziemnego, a także relacje panujące między nimi a polskimi komunistami oraz przedstawicielami Armii Czerwonej i NKWD.

\section{What Happened in Lublin in Late June and Early July of 1944 ? A Contribution to the Political History of Poland}

The article is devoted to the events that took place in Lublin at the end of July and in the early August of 1944. At that time, as the Red Army approached the city, a decision was made to disclose the civil structures of the Polish Underground State the primary purpose of which was to take over power in the areas abandoned by the German forces. The action was to be carried out simultaneously with the military operation of the Home Army as part of the Operation "Tempest". Polish communists supported by the Kremlin were also preparing to take over power in the territories freed from German occupation. Initially, they tried to persuade the representatives of the Polish Delegation to resign from their positions, and when it failed, urged them to cooperate with the Polish Committee of National Liberation. Over time, the conflict between the two political centres intensified. After a few days of open activity, local representatives of the emigration authorities were arrested by the Soviets and transported to the USSR, where they were sent to camps administered by the NKVD. The present article is an attempt to reconstruct the events that took place in Lublin in the period between the withdrawal of the Germans in the third decade of July and the arrest of the representatives of the Home Army Lublin District and the Lublin Voivodeship Government Delegation. Special emphasis was put on the activities of the administration of the Polish Underground State and the relations between them and the Polish communists and representatives of the Red Army and the NKVD.

\section{Bibliografia}

Alef-Bolkowiak G., Gorqce dni, Warszawa 1971.

Bączyk N., Czotgi ida na Lublin. Radzieckie wojska pancerne w szturmie Lublina w lipcu 1944 r., „Militaria XX Wieku” 2006, nr 1 (10).

Caban I., Co się działo 22 lipca?, „Kamena”, 15 IV 1979, nr 8, s. 7. 
Caban I., Lublin w okresie wyzwolenia (22-31 lipca 1944), „Rocznik Lubelski” 1966, t. IX, s. $353-369$.

Caban I., Lublin, lipiec '44, Lublin 1984.

Caban I., Ludzie Lubelskiego Okregu Armii Krajowej, Lublin 1995.

Chabros T., Kronika wydarzeń w Lublinie 21 VII 1944 - 1 II 1945, Lublin 1974.

Chmielarz A., Władze sowieckie i PKWN wobec AK w 1944 r., „Wojskowy Przegląd Historyczny" R. 37, 1992, nr 2, s. 17-38.

Eisler J., Siedmiu wspaniatych. Poczet pierwszych sekretarzy KC PZPR, Warszawa 2014.

Gawryszczak P., Podziemie polityczno-wojskowe w Inspektoracie Lublin w latach 1944-1956, Lublin 1998.

Gawryszczak P., Powstanie $i$ upadek konspiracji antyniemieckiej $i$ antysowieckiej $w$ Inspektoracie Lublin, w: Podziemie zbrojne na Lubelszczyźnie wobec dwóch totalitaryzmów 1939-1956, red. S. Poleszak, A. Puławski, Warszawa 2002, s. 52-56.

Gontarczyk P., Jak krawiec rozwiazat generalski problem, czyli prawda o PKWN, „Gazeta Polska”, 21 VII 2004, nr 29, s. 19-21.

Gontarczyk P., Polska Partia Robotnicza. Droga do władzy 1941-1944, Warszawa 2006.

Grabowski W., Polska Tajna Administracja Cywilna 1940-1945, Warszawa 2003.

Grabowski W., Rada Jedności Narodowej - parlament Polskiego Państwa Podziemnego, „Pamięć i Sprawiedliwość” 2002, nr 2 (2), s. 67-93.

Grabowski W., Rola administracji cywilnej w akcji „Burza”, w: Administracja cywilna Polskiego Państwa Podziemnego i jej funkcje w okresie powstania warszawskiego, red. J. Czaputowicz, Warszawa 2011.

Iwanow N., Powstanie Warszawskie widziane z Moskwy, Kraków 2010.

Jachymek J., Wtadystaw Cholewa (1892-1962). Ludowiec wzorowy, w: M. Mazurek, Wtadystaw Cholewa. Delegat Rzadu Londyńskiego na województwo lubelskie. Sybirak. Biografia, Czemierniki 2012, s. III-VIII.

Kallas M., Historia ustroju Polski, Warszawa 2007.

Kasperek J., Kronika wydarzeń w Lublinie w okresie okupacji hitlerowskiej, Lublin 1989.

Kasperska A., Lublin 44: To byt tragiczny widok, „Kurier Lubelski”, 2 VIII 2012, nr 179, s. 6.

Kersten K., Dyplomacja polska w poszukiwaniu kompromisu polsko-sowieckiego (kwiecieńlistopad 1944), w: Historia dyplomacji polskiej, t. V, red. W. Michowicz, Warszawa 1999, s. $491-572$.

Kister A., Plany powstania powszechnego i operacji „Burza” na Lubelszczyźnie, 1943-1944, „Przegląd Historyczno-Wojskowy” 2003, nr 3, s. 141-150.

Kospath-Pawłowski E., Chwała i zdrada. Wojsko Polskie na Wschodzie 1943-45, Warszawa 2010.

Kuszyk W., Szczepański S., Pierwsze dni Wojewódzkiej Rady Narodowej w Lublinie (lipiec 1944), oprac. I. Caban, „Rocznik Lubelski” 1964, t. VII, s. 195-210.

Lisiewicz P., Plan „Burza”. Wysitek zbrojny Armii Krajowej 1944-1945, Warszawa 1990.

Łochowski M., Dziesięć dni Antoniego Wiacka. Działalność Powiatowej Delegatury Rzqdu RP w Zamościu 25 lipca - 3 sierpnia 1944 roku, w: Zimowa Szkoła Historii Najnowszej 2016. Referaty, red. M. Przeperski, Ł. Kamiński, Warszawa 2017, s. 40-47.

Mańkowski Z., Okręg Lublin, w: Operacja „Burza” i Powstanie Warszawskie 1944, red. K. Komorowski, Warszawa 2008, s. 259-274.

Marczuk J., Prezydenci miasta Lublina 1918-1939, Lublin 1994.

Markiewicz J., Powiatowa Delegatura Rzadu Rzeczypospolitej Polskiej w Bitgoraju 29 VII 1944 - 8 VII 1944 r. (Próba zarysu $i$ analizy), w: Nad Tanwia $i$ Łada. Przyczynki do historii i kultury Ziemi Bitgorajskiej, Biłgoraj 2006, s. 31-49.

Motyka G., Na białych Polaków obława. Wojska NKWD w walce z polskim podziemiem 1944-1953, Kraków 2014. 
Myśliński J., Prasa w Polsce Ludowej, w: J. Łojek, J. Myśliński, W. Władyka, Dzieje prasy polskiej, Warszawa 1998.

Noskowa A., Na drodze do stworzenia PKWN - rola Moskwy, „Pamięć i Sprawiedliwość” 2005, nr 2 (4), s. 31-49.

Poksiński J., Żotnierze Armii Krajowej w ludowym Wojsku Polskim, w: Armia Krajowa. Dramatyczny epilog, red. K. Komorowski, Warszawa 1994, s. 131-151.

Romanek J., Milicja Obywatelska, w: Dzieje Lubelszczyzny 1944-1956. Aspekty polityczne, red. T. Osiński, M. Mazur, Lublin 2016, s. 227-237.

Sacewicz K., Centralna prasa Polski Podziemnej wobec komunistów polskich 1939-1945, Warszawa 2009.

Skrzypek A., Mechanizmy uzależnienia. Stosunki polsko-radzieckie 1944-1957, Pułtusk 2002.

Sowa A., Od Drugiej do Trzeciej Rzeczypospolitej (1945-2001), Kraków 2001.

Strzembosz T., Burza na Lubelszczyźnie, „Biuletyn Informacyjny” 2004, t. XIV, nr 5, s. 7-18.

Wawryniuk A., Plany polityczne Chruszczowa w sprawie wtaczenia części powiatu radzyńskiego do Ukraińskiej Socjalistycznej Republiki Sowieckiej, „Radzyński Rocznik Humanistyczny” 2012, t. X, s. 50-66.

Wawryniuk A., Wschodnia granica Polski w latach 1944-1948 na przykładzie południowo-wschodniej Lubelszczyzny, „Archiwariusz Zamojski” 2012, s. 7-46.

Wendel A., KRN i PKWN - pierwsze władze Polski Ludowej, „Rocznik Lubelski” 1959, t. II, s. $15-24$.

Wierzbicki M., Polska lubelska (1944 r.), w: Dzieje Lubelszczyzny 1944-1956. Aspekty polityczne, red. T. Osiński, M. Mazur, Lublin 2016, s. 73-86.

Wołczew W., Przebieg realizacji planu „Burza” na Lubelszczyźnie, „Rocznik Lubelski” 1962, t. V, s. 213-234.

Wrona J., Lublin w okresie Polskiego Komitetu Wyzwolenia Narodowego, w: Lublin w dziejach i kulturze Polski, red. T. Radzik, A. Witusik, Lublin 1997, s. 365-382.

Zych-Dolina J., Pamiętny lipiec w Lublinie, „Kultura” 1950, nr 7-8 (33-34), s. 166-188.

Żenczykowski T., Polska lubelska 1944, Warszawa 1990.

Biogram: Maciej Lochowski - doktorant w Instytucie Historii Katolickiego Uniwersytetu Lubelskiego Jana Pawła II, pracownik Instytutu Pamięci Narodowej. Zainteresowania badawcze: historia podziemia zbrojnego działającego na obszarze Polski w czasie II wojny światowej, działalność PKWN, opór względem władz komunistycznych. E-m ail: lochowski. maciej@gmail.com. 